Polymorphism Report

\title{
A G-to-A single nucleotide polymorphism in the human Alpha 2 Delta 2 calcium channel subunit gene that maps at chromosome $3 p 21.3$
}

\author{
D. Angeloni, ${ }^{1 *}$ M.-H. Wei, ${ }^{2}$ F.-M. Duh, ${ }^{2}$ B. E. Johnson ${ }^{3}$ and M. I. Lerman ${ }^{1}$ \\ ${ }^{1}$ Laboratory of Immunobiology, National Cancer Institute_Frederick Cancer Research \\ and Development Center, Frederick, MD 21702-1201, USA, ${ }^{2}$ Intramural Research \\ Support Program, SAIC Frederick, MD 21702-1201, USA and ${ }^{3}$ Medicine Branch at \\ the Navy, National Cancer Institute, National Institutes of Health, Bethesda,
} MD 20892, USA

(Received 15 September 1999, Accepted 15 November 1999)

KEYWORDS: Alpha 2 Delta subunit 2 calcium channel gene, single nucleotide polymorphism (SNP), loss of heterozygosity LOH, lung cancer.

\section{SOURCE/DESCRIPTION}

A single nucleotide polymorphism (SNP) in the human Alpha 2 Delta subunit 2 calcium channel gene (CACNA2D2; GenBank accession \#AF042792) was found by single-strand conformation polymorphism (SSCP) method, during mutation analysis of normal/tumor paired DNA samples obtained from lung cancer patients. ${ }^{1,2}$ The Alpha 2 Delta 2 gene maps at 3p21.3, in the region that most frequently undergoes loss of heterozygosity $(\mathrm{LOH})$ in lung cancer. The polymorphism consists of a G-to-A transition (Fig. 1), it is intronic and located on cosmid LUCA 11 (GenBank accession \#Z84492). The allele ' $A$ ' has an index of heterozygosity of $23 \%$ among lung cancer patients and $8 \%$ in a group of $\mathrm{CEPH}^{3}$ control individuals.

The G-to-A transition creates an Alul restriction site that cleaves into two fragments of 172 and $63 \mathrm{bp}$, the $235 \mathrm{bp}$ PCR product obtained with the primers indicated below.

\section{PRIMER SEQUENCES}

MJE7 Fw: 5'-GGA GGG CTG AGA GCT GCC TG MJE7 Rv: 5'-TTG AGG TTA CTG CTG TGG CCA C

\section{PCR-SSCP analysis}

A total of $100 \mathrm{ng}$ of DNA was used per each reaction. Normal DNA was extracted from peripheral white blood cells, tumor DNA from surgically resected tumor tissue. The radioactive PCR was performed in a total reaction volume of $12.5 \mu \mathrm{l}$, containing, $12.5 \mathrm{pmol}$ of each primer, $200 \mu \mathrm{m}$ dNTPs, $1.5 \mathrm{~mm}$ $\mathrm{MgCl} 2,1 \cdot 25 \mathrm{nCi} \alpha 35 \mathrm{~S}$-dATP. Primers amplify a single product under the following cycling conditions: $3 \mathrm{~min}$ at $95^{\circ} \mathrm{C} ; 35 \times\left(1 \mathrm{~min}\right.$ at $95^{\circ} \mathrm{C}, 30 \mathrm{~s}$ at $62^{\circ} \mathrm{C}, 1 \mathrm{~min}$ at $\left.72^{\circ} \mathrm{C}\right) ; 7$ min at $72^{\circ} \mathrm{C}$. After heat denaturation $(8 \mathrm{~min}$ at $90^{\circ} \mathrm{C}$ ) in formamide buffer (Stop Solution, Amersham, Arlington Heights IL, USA), PCR products (235 bp)

\footnotetext{
* Author to whom all correspondence should be addressed at: Laboratory of Immunobiology, National Cancer Institute-Frederick Cancer Research and Development Center, Frederick, MD 21702-1201, USA. Tel: +1 301846 1288, Fax: +1 301 846 6145, E-mail: andreazzolid@mail.ncifcrf.gov
} 

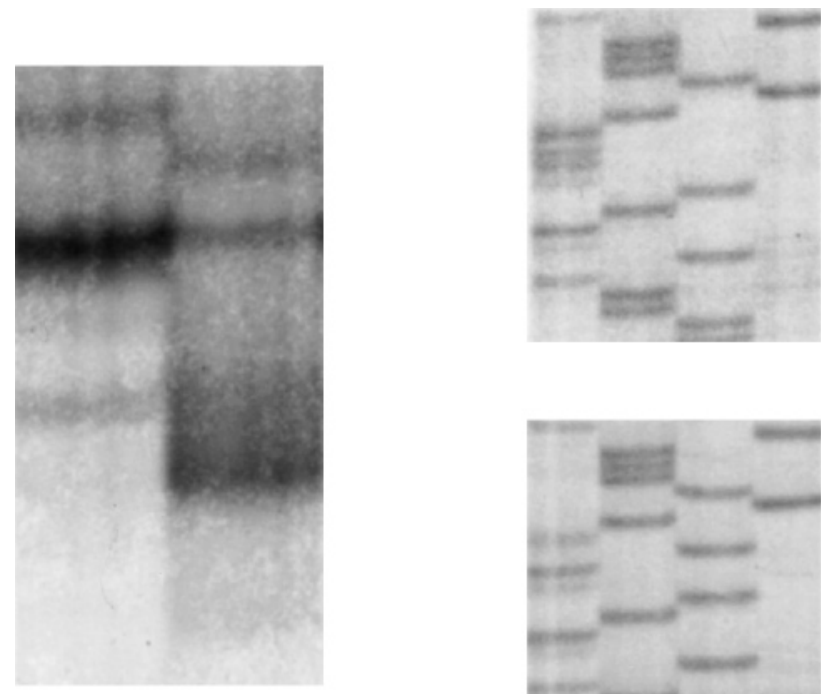

a

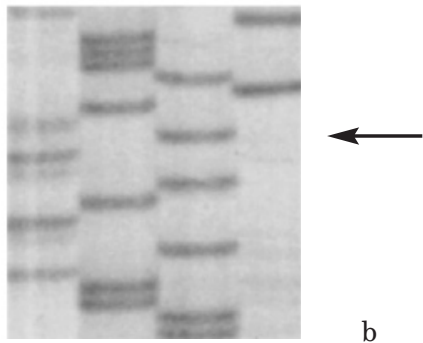

Fig. 1. SSCP analysis of the Alpha 2 Delta 2 calcium channel gene in lung cancer patients, by means of MJE7 primers, revealed the presence of an intronic SNP. Lane 1: migration profile given by the more frequent allele ' $\mathrm{G}^{\prime}$ (sequence in inset a); Lane 2: profile of the allele ' $A$ ' (sequence in inset b), which was found in six out of 23 lung cancer patients and two out of $24 \mathrm{CEPH}$ individuals.

were run overnight in a $0.5 \times \mathrm{MDE}$ gel (FMC Bioproducts, Rockland ME, USA), $0.6 \times \mathrm{TBE}$, at RT, $8 \mathrm{~W}$ constant power; transferred on $3 \mathrm{MM}$ paper, dried and exposed to autoradiography film (X-OMAT AR, USA, Kodak, Rochester NY, USA).

\section{SEQUENCING}

Sequencing reactions were done either manually (T7 Sequenase Kit, Amersham, Arlington Heights IL, USA) or automatically (ABI 373 Stretch Automated DNA Sequencer, Applied Biosystems, Foster City CA, USA).

\section{FREQUENCY}

Twenty-three pairs of normal/tumor DNA, obtained from lung cancer patients, were analysed. Six individuals (paired samples number: 34/856; 8906/ $8361 ; 848 / 1237$ and $1245 / 963$, affected with small cell lung cancer; 932/1192 and 5364/5360, affected with non-small-cell lung cancer), were found heterozygous for the allele ' $A$ ' (Fig. 1). The polymorphic allele was found in two $\mathrm{CEPH}^{3}$ control individuals (45-01 and 1344-01) out of 24 analysed. The allele 'A' index of heterozygosity corresponds to $23 \%$ among lung cancer patients, and to $8 \%$ in the control population. Further studies are ongoing, on a larger sample of lung cancer patients and control individuals, to better estimate these values.

\section{ACKNOWLEDGEMENTS}

This project has been funded in toto with Federal funds from the National Cancer Institute, National Institutes of Health, under Contract No. NO1-CO-56000. The content of the publication does not necessarily reflect the views or policies of the Department of Health and Human Services, nor does mention of trade names; commercial products, or organizations imply endorsement by the US Government.

(C) 2000 US Government

\section{REFERENCES}

1. Johnson, B. E., Makuch, R. W., Simmons, A. D., Gazdar, A. F., Burch, D., Cashell, A. W. (1988). myc family DNA amplification in small cell lung cancer patients' tumors and corresponding cell lines. Cancer Research 48, 5163-6.

2. Phelps, R. M., Johnson, B. E., Ihde, D. C., Gazdar, A. F., Carbone, D. P., McClintock, P. R. et al. (1996). NClNavy Medical Oncology Branch cell line data base. Journal of Cellular Biochemistry 24, 32-91.

3. Dausset, J., Cann, H., Cohen, D., Lathrop, M., Lalouel, J. M., White, R. (1990). Centre d'etude du polymorphisme humain $(\mathrm{CEPH})$ : collaborative genetic mapping of the human genome. Genomics 6, 575-7. 